\title{
ENTITAS WISATAWAN ASING TERHADAP KEMAMPUAN BERBAHASA INGGRIS MASYARAKAT LOKAL BANJAR TEGAL GUNDUL, DESA TIBUBENENG, KUTA UTARA, BADUNG, BALI
}

\author{
Ni Nyoman Widani ${ }^{1}$, Wiya Suktiningsih ${ }^{2}$ \\ nyoman.widani@pib.ac.id ${ }^{1}$, wiya.suktiningsih@universitasbumigora.ac.id, ${ }^{2}$ \\ Politeknik Internasional Bali, Universitas Bumigora
}

\begin{abstract}
Banjar Tegal Gundul is one of the tourist villages in the village area of Tibubeneng, North Kuta, Badung, Bali, which receives visits by foreign and domestic tourists. Every year the number of foreign and domestic tourist arrivals to the Banjar Tegal Gundul region has increased. The situation makes the tourism sector as the main livelihood of the local community Banjar Tegal Gundul. The situation is the background of this research, namely: 1) to find out how the influence of foreign tourist entities on the English language ability of local people in Banjar Tegal Gundul and 2) how the attitude of the local people's language towards English. The research uses the method of observation and distributes questionnaires to 24 respondents, who are local people as workers and business owners who are in the area of the area. The step taken in this study is to analyze the language functions used by local people when communicating with foreign tourists. The results obtained in this study indicate that local people are able to communicate with foreign tourists, by using language functions such as: Greeting, Offering, asking for information, giving information, Saying Like, Giving opinion, persuading, asking someone to do something, Accepting invitation, apologizing, persuading, and saying / reply to thank. The sentences are used in accordance with grammatical rules in English. For language attitudes towards English seen from the cognitive, affective and conative components, showing positive language attitudes by local people towards English. That is because the equality of local people's thought orientation will benefit from English, for the livelihoods of local people, both in terms of workers or business owners in the Banjar Tegal Gundul region.
\end{abstract}

Keywords: entities, tourism, English, language functions, language attitudes

\begin{abstract}
ABSTRAK
Banjar Tegal Gundul merupakan salah satu desa wisata yang ada di wilayah desa Tibubeneng, Kuta Utara, Badung, Bali, yang menerima kunjungan wisatawan asing dan domestik. Setiap tahunnya angka kedatangan wisatawan asing dan domestik ke daerah wilayah Banjar Tegal Gundul mengalami peningkatan. Keadaan tersebut menjadikan
\end{abstract}




\section{Oeumanitatis}

Journal on Language and Literature Vol. 6 No. 2 June 2020

sektor pariwisata sebagai mata pencaharian utama masyarakat lokal Banjar Tegal Gundul. Keadaan tersebut menjadi latar belakang penelitian ini dilakukan yaitu: 1) untuk mengetahui bagaimana pengaruh entitas wisatawan asing terhadap kemampuan berbahasa Inggris masyarakat lokal Banjar Tegal Gundul dan 2) bagaimana sikap bahasa masyarakat lokal terhadap bahasa Inggris. Penelitian menggunakan metode observasi dan menyebarkan kuesioner kepada 24 responden, yang merupakan masyarakat lokal sebagai pekerja dan pemilik usaha yang berada di wilayah daerah tersebut. Langkah yang dilakukan pada penelitian ini adalah menganalisa fungsi-fungsi bahasa yang digunakan oleh masyarakat lokal ketika berkomunikasi dengan wisatawan asing. Hasil yang diperoleh dalam penelitian ini menunjukkan bahwa masyarakat lokal mampu berkomunikasi dengan para wisatawan asing, dengan mempergunakan fungsi bahasa seperti: Greeting, Offering, asking for information, giving information, Saying Like, Giving opinion, persuading, asking someone to do something, Accepting invitation, apologizing, persuading, dan say/reply to thank. Adapun kalimat yang digunakan sesuai dengan kaidah gramatikal dalam bahasa Inggris. Untuk sikap bahasa terhadap bahasa Inggris dilihat dari komponen kognitif, afektif dan konatif, menunjukan sikap bahasa yang positif oleh masyarakat lokal terhadap bahasa Inggris. Hal tersebut dikarenakan persamaan orientasi pemikiran masyarakat lokal akan manfaat dari bahasa Inggris, bagi mata pencaharian masyarakat lokal, baik dari sisi pekerja atapun pemilik usaha yang ada diwilayah Banjar Tegal Gundul.

Keywords: entitas, pariwisata, bahasa Inggris, fungsi bahasa, sikap bahasa

\section{A. PENDAhUluan}

Pulau Bali sudah sangat popular bagi para traveler di Dunia untuk datang berlibur dan menikmati suasana pulau Bali. Menurut survei pembaca Condé Nast Traveler yang merupakan majalah perjalanan dan gaya hidup yang terkenal di New York, menyatakan ada 30 pulau wisata terbaik didunia yang dijadikan pilihan destinasi wisata. Bali termasuk urutan ke 5 sebagai pulau wisata terbaik di wilayah Asia. Pulau Bali disebutkan sebagai tempat terbaik liburan bersama keluarga, selain terkenal dengan pesona pantainya, kuliner tradisionalnya, budaya masyarakat dan juga panorama alam pulau Bali yang indah. Data statistik tahun 2020 menyatakan jumlah penduduk pulau Bali hampir mencapai angka 4.400.000 dan memiliki mata pencaharian sebagai petani, pedagang, pengrajin, pegawai dan penyedia jasa yang berhubungan dengan sektor pariwisata. Perkembangan sektor pariwisata memberikan dampak bagi perekonomian masyarakat khususnya daerah 


\section{Oeumanitatis}

Journal on Language and Literature Vol. 6 No. 2 June 2020

Banjar Tegal Gundul, Desa Tibubeneng, Kecamatan Kuta Utara, Kabupaten Badung yang letaknya dekat dengan destinasi wisata. Kedatangan wisatawan domestik dan internasional tiap tahunnya mengalami peningkatan setiap tahunnya. Data BPS pemerintahan Bali menyatakan bahwa jumlah wisatawan yang berkunjung ke Bali pada bulan Desember 2019 naik 16,0\% dibandingkan dengan bulan Januari 2019. Dan mencatat 5 (lima) besar Negara wisatawan yang datang berkunjung ke Bali berasal dari Tiongkok (21,0\%), Australia (19,49\%), India $(5,63 \%)$, Rusia $(4,82 \%)$ dan Korea Selatan 94,45\%). Dari persentase wisatawan yang ada, wisatawan yang berasal dari Australia yang memiliki waktu tinggal lebih lama dan bahkan banyak yang menetap dengan mnyewa villa atau guest house, juga beberapa wisatawan asing yang membuka berbagai usaha yang berhubungan dengan usaha jasa pariwisata seperti, hotel, restaurant, café, villa, garmen dan property. Keadaan tersebut sangat mendukung kemajuan perekonomian dan membuka lapangan kerja bagi masyarakat di Bali khususnya masyarakat sekitar Banjar Tegal Gundul, Badung. Para wisatawan Australia yang menetap ataupun yang membuka usaha disekitar banjar Tegal Gundul-Badung, menggunakan bahasa Inggris ketika berinteraksi dengan masyarakat dan para pekerjanya yang kebanyakan berasal dari lingkungan sekitar. Kemampuan berbahasa Inggris juga menjadi salah satu persyaratan utama seorang pekerja, selain untuk memudahkan komunikasi antara owner dan pekerjanya, kemampuan berbahasa Inggris juga memudahkan pekerja ketika berinteraksi dengan wisatawan. Masyarakat secara tidak langsung diwajibkan untuk menggunakan bahasa Inggris sebagai alat komunikasi ketika berintreraksi dengan para wisatawan. Kemampuan berbahasa Inggris akan menjadi salah satu indikator yang harus dilakukan dan dijadikan persyaratan dalam penerimaan karyawan. Dengan memiliki kemapuan berbahasa Inggris yang baik akan mempermudah komunikasi serta bisa memberikan pelayanan yang lebih baik kepada para wisatawan. Adanya interaksi para wisatawan asing dengan masyarakat lokal Tegal Gundul menciptakan situasi kebahasaan masyarakat yang beragam. Masyarakat lokal belum siap menghadapi lajunya perkembangan kepariwisataan yang ada, sehingga menjadi suatu kendala 


\section{Oeumanitatis}

Journal on Language and Literature Vol. 6 No. 2 June 2020

bagi masyarakat lokal ketika berhadapan langsung dengan para wisatawan asing yang sebelumnya selalu menggunakan jasa tour guide atau penterjemah. Sering terjadinya miss understanding (salah paham) ketika melakukan transaksi/komunikasi, karena kurangnya penguasaan bahasa Inggris. Melihat fenomena tersebut, keberadaan kursus bahasa Inggris menjadi sangat diperlukan saat ini. Memperdalam dan belajar bahasa inggris yang cepat dan praktis menjadi perhatian untuk dilakukan saat ini. Belajar yang menitik beratkan pada percakapan atau komunikasi langsung. Keadaan ini mendapat reaksi cepat oleh kepala lingkungan (Kelian Dinas) Banjar Tegal Gundul, dengan melihat potensi yang ada dalam meningkatkan SDM masyarakat untuk kedepannya, maka di buat program dengan memberikan pelatihan bahasa Inggris pemula kepada generasi muda yaitu mulai dari anak-anak Sekolah Dasar dan Sekolah Menengah Pertama yang ada di lingkungan Banjar Tegal Gundul. Antusias yang tinggi dari setiap masyarakat lokal Banjar Tegal Gundul dari pentingnya memiliki kemampuan berbahasa Inggris dalam berkomunikasi ketika melakukan transaksi dengan para wisatawan asing, atau hanya sekedar berbincang-bincang, mendorong masyarakat lokal untuk mempelajari bahasa Inggris lebih jauh. Berdasarkan latar belakang tersebut di atas, penelitian ini dilakukan untuk :1) mengetahui bagaimana pengaruh entitas wisatawan asing terhadap kemampuan berbahasa Inggris masyarakat lokal Banjal Tegal Gundul, melalui fungsi bahasa yang digunakan oleh masyarakat lokal ketika berkomunikasi dengan wisatawan asing, dan 2) bagaimana sikap bahasa masyarakat lokal terhadap bahasa Inggris, dilihat dari komponen konitif, afektif dan konatif.

\section{B. TINJAUAN PUSTAKA}

\section{Fungsi Bahasa}

Dalam suatu peristiwa tutur/wicara menurut Fishman (1972b, P.46) dipengaruhi oleh beberapa faktor yaitu who speaks (or write), what language, to whom and what the end, hal tersebut adalah alur situasi kebahasaan yang terjadi pada umumnya dimasyarakat. Dari faktor bahasa Blundell (1987: 5), menyatakan 


\section{Oeumanitatis}

Journal on Language and Literature Vol. 6 No. 2 June 2020

fungsi bahasa merupakan tujuan suatu komunikasi atau tujuan suatu tulisan. Diketahui bahwa apa yang dilaksanakan termasuk didalamnya menggunakan bahasa, memiliki tujuan. Setiap bahasa memiliki fungsi bahasa, dan memiliki cara tersendiri dalam mengekspresikan fungsi bahasa tersebut. Fungsi bahasa didasarkan atas situasi wicara, yaitu dari segi formal dan informal. Ekspresi bahasa di dalam bahasa Inggris di bagi menjadi tiga, yaitu (1) ekspresi formal yang digunakan dalam situasi formal; (2) ekspresi informal yang digunakan dalam situasi informal; dan (3) ekspresi netral, yaitu ekspresi yang dapat digunakan baik dalam situasi formal dan informal. Blundell membagi fungsi bahasa menjadi beberapa kelompok, yaitu:

1) Main Function, yaitu fungsi yang berkenaan dengan informasi (information), sikap (attitude), dan tindakan (attitude). Misalnya: asking and giving information, reminding, remembering, expressing surprise, saying like and dislikes, comparing, giving opinion, offering, warning, requesting, dan lainlain.

2) Social Formula, seperti: introducing someone (fungsi untuk memperkealkan diri sendiri atau orang lain), inviting someone, accepting invitation, greeting, ending conversation, thanking, saying goodbye.

3) Making communication work, misalnya: Asking someone to say something again, repeating something, showing you are listening, changing the subject.

4) Finding out about language, misalnya: finding about spelling, correctness, and meaning.

Untuk mengukur kemampuan berbahasa Inggris dapat dianalisa melalui fungsi-fungsi bahasa yang digunakan oleh penutur dalam suatu peristiwa tutur/wicara. Dan juga dapat dilihat dari ekspresi ataupun respon dari mitra tuturnya, apakah respon yang diberikan sesuai dengan tujuan dari peristiwa tutur/wicara tersebut. Jika tujuan itu tercapai maka dapat disimpulkan bahwa penutur memiliki kemampuan berbahasa Inggris yang baik. 


\section{Oeumanitatis}

Journal on Language and Literature Vol. 6 No. 2 June 2020

\section{Sikap Bahasa}

Kemampuan penutur berbahasa dapat dilihat dari sikap bahasa positif yang ditunjukan oleh penutur. Sikap bahasa (language attitude) adalah sikap seseorang terhadap suatu bahasa dan juga terhadap penggunaan bahasa tersebut. Menurut kridalaksana (2001:197) Sikap bahasa adalah posisi mental atau perasaan terhadap bahasa sendiri atau bahasa orang lain yang digunakan oleh seorang penutur. Sikap bahasa seorang penutur dapat terbentuk oleh faktor yang datang dari luar (faktor eksternal) dan faktor dari dalam (faktor internal). Partana dan Sumarsono (2004) bahwa faktor internal dapat berupa pengalaman pribadi, daya seleksi, hasil pendidikan keluarga, sedangkan faktor eksternal, adalah: lembaga pendidikan formal, orang lain yang dianggap berpengaruh, kontak dengan budaya lain, media masa, dan lapangan pekerjaan. Dari pernyataan tersebut dapat dikatakan bahwa sikap merupakan fenomena kejiwaan, yang biasanya termanifestasi dalam bentuk tindakan atau perilaku. Sikap Bahasa tidak dapat diamati secara langsung. Untuk mengamati sikap dapat dilihat melalui perilaku, tetapi dari berbagai hasil penelitian menunjukkan bahwa apa yang nampak dalam perilaku tidak selalu menunjukkan sikap. Begitu juga sebaliknya, sikap Bahasa seseorang tidak selamanya tercermin dalam perilakunya. Oleh karena itu untuk menganalisa sikap Bahasa penutur terhadap suatu Bahasa maka Lambert dan Chaer (2010:150) menyatakan untuk mengamati sikap Bahasa dari tiga komponen, yaitu komponen kognitif, komponen afektif, dan komponen konatif.

Komponen kognitif berhubungan dengan pengetahuan mengenai alam sekitar dan gagasan yang biasanya merupakan kategori yang dipergunakan dalam proses berpikir. Komponen afektif menyangkut masalah penilaian baik, suka atau tidak suka terhadap sesuatu atau suatu keadaan. Jika seseorang memiliki nilai rasa baik atau suka terhadap sesuatu keadaan, maka orang itu dikatakan memiliki sikap positif. Jika sebaliknya, disebut memiliki sikap negatif. Komponen konatif

menyangkut perilaku atau perbuatan sebagai "putusan akhir" kesiapan reaktif terhadap suatu keadaan. 


\section{OUmanitatis}

Journal on Language and Literature Vol. 6 No. 2 June 2020

Melalui ketiga komponen sikap inilah orang biasanya mencoba menduga bagaimana sikap seseorang terhadap suatu keadaan yang sedang dihadapinya. Ketiga komponen sikap ini sangat berhubungan erat dengan sikap bahasa seseorang. Berdasarkan pendapat di atas dapat dikatakan bahwa sikap bahasa yang positif terhadap suatu bahasa akan mendorong seseorang berusaha lebih baik untuk menguasai suatu bahasa. dalam hal ini teori sikap bahasa digunakan untuk mengetahui sikap bahasa masyarakat lokal Banjar Tegal Gundul, Desa Tibubeneng, Kuta Utara, Badung, Bali terhadap bahasa Inggris.

\section{METODE PENELITIAN}

Suharsimi, A. (1989). Arikunto. Jakarta: Bina Angkasa.

Penentuan suatu jenis suatu penelitian dapat di tinjau dari beberapa indikator yaitu tujuan, pendekatan penelitian, bidang ilmu yang diteliti dan lokasi penelitian. Penelitian ini menggunakan pendekatan deskriptif kuantitatif dalam pengumpulan data digunakan metode observasi untuk mengamati fungsi Bahasa yang digunakan oleh masyarakat lokal dan bentuk ekspresi wisatawan asing sebagai tujuan untuk penggunaan fungsi Bahasa tersebut. Metode survei (kusioner) digunakan untuk mengukur instrumen berupa kuesioner dalam mengukur sikap terhadap Bahasa Inggris. Sikap akan diukur dengan angka-angka untuk mengetahui skala sikap dapat dinyatakan positif atau negatif.

Pendekatan deskriptif kualitatif digunakan untuk menjabarkan sikap berdasarkan aspek linguistik dan faktor-faktor yang memengaruhi sikap terhadap Bahasa Inggris.

Penelitian ini dilakukan di lingkungan Banjar Tegal Gundul, Desa Tibubeneng, Kuta Utara, Badung, Bali. Daerah yang berada dekat dengan daerah pesisir pantai seperti: pantai Berawa, pantai Batu Belig, pantai Kayu Putih dan pantai Batu Bolong. Daerah tersebut dipilih sebagai lokasi penelitian karena banyak dikunjungi wisatawan Asing, khususnya wisatawan Australia untuk melakukan surfing (berselancar) dan menikmati sunset (pemandangan matahari terbenam). Di daerah 


\section{Oeumanitatis}

Journal on Language and Literature Vol. 6 No. 2 June 2020

pantai tersebut juga banyak ditemui masyarakat Banjar Tegal Gundul yang membuka usaha sebagai pedagang makanan dan minuman, penyewaan papan surfing dan kendaraan bermotor ataupun sebagai pekerja di Villa/Guest House/Hotel yang dihuni para wisatawan asing tersebut, sehingga interaksi intents antara masyarakat Banjar Tegal Gundul dengan wisatawan Australia mudah ditemukan dan hal tersebut mempermudah kegiatan observasi pada penelitian ini.

Kuesioner yang digunakan untuk mengetahui data sikap adalah kuesioner dengan jenis skala Likert, yaitu model kuesioner dengan jenis pertanyaan yang jawabannya Sangat Setuju (SS), Setuju (S), Netral (N), Tidak Setuju (TS), dan Sangat Tidak Setuju (STS), dengan skala terbesar yaitu lima sampai terkecil satu untuk jawaban tiap pertanyaan.

Informan dalam penelitian ini adalah masyarakat lokal Banjar Tegal Gundul, Desa Tibubeneng, Kecamatan Kuta Utara, Kabupaten Badung, Bali. Informan berjenis kelamin lelaki ataupun perempuan yang sudah dewasa, kisaran usia 2645 tahun. Pekerjaan informan adalah yang berhubungan dengan aktivitas wisata, seperti pemilik hotel, villa, guest house, café, restoran, penyewaan kendaraan bermotor, penjual makanan dan minuman di daerah objek wisata.

Hasil analisis data sikap bahasa terhadap bahasa Inggris disajikan dalam bentuk tabel dan narasi. Persentase dalam table digunakan untuk mendeskripsikan data sikap bahasa terhadap Bahasa Inggris. Data mengenai faktor yang mempengaruhi sikap bahasa dan bagaimana pengaruhnya terhadap kemampuan berbahasa Inggris disajikan dalam bentuk table dan narasi.

\section{TEMUAN PENELITIAN DAN PEMBAHASAN}

Hasil penelitian akan di uraikan dalam dua bagian yaitu: Pengaruh Entitas Wisatawan Asing terhadap kemampuan berbahasa Inggris masyarakat lokal Banjar Tegal Gundul yang di dapatkan dari hasil questioner yang di sebarkan terhadap 24 responden dan dianalisa mempergunakan teori berdasarkan teori dari Blundell (1987:5) dan Sikap Bahasa Masyarakat Lokal Banjar Tegal Gundul, Desa Tibubeneng, Kuta Utara, Badung, Bali terhadap Bahasa Inggris yang di peroleh 


\section{Pumanitatis}

Journal on Language and Literature Vol. 6 No. 2 June 2020

dari hasil wawancara terhadap masyarakat lokal yg berprofesi sebagai pekerja maupun pemilik usaha, mempergunakan teori Sikap bahasa Menurut Chaer dan Agustina (2010:149). Sikap bahasa tersebut meliputi tiga bagian atau komponen, yakni komponen kognitif, komponen afektif, dan komponen konatif.

\section{1 . Pengaruh Entitas Wisatawan Asing Terhadap Kemampuan Berbahasa Inggris Masyarakat Lokal Banjar Tegal Gundul}

Responden yang terlibat dalam penelitian ini memiliki status sebagai pekerja ataupun pemilik usaha di sektor pariwisata, yang berada di wilayah Banjar Tegal Gundul Desa Tibubeng Kuta Utara Kabupaten Badung Provinsi Bali. Sektor pariwisata menjadi salah satu mata pencaharian utama bagi masyarakat sekitar. Pada proses pengumpulan data survei melalui kusioner diperoleh data bahwa 83, 3 $\%$ dari responden mengatakan Sangat Setuju dan 18, 7\% Setuju bahwa entitas wisatawan asing yang datang menjadi salah satu faktor yang mendorong mereka untuk mempelajari Bahasa Inggris, berikut data dari hasil survei:

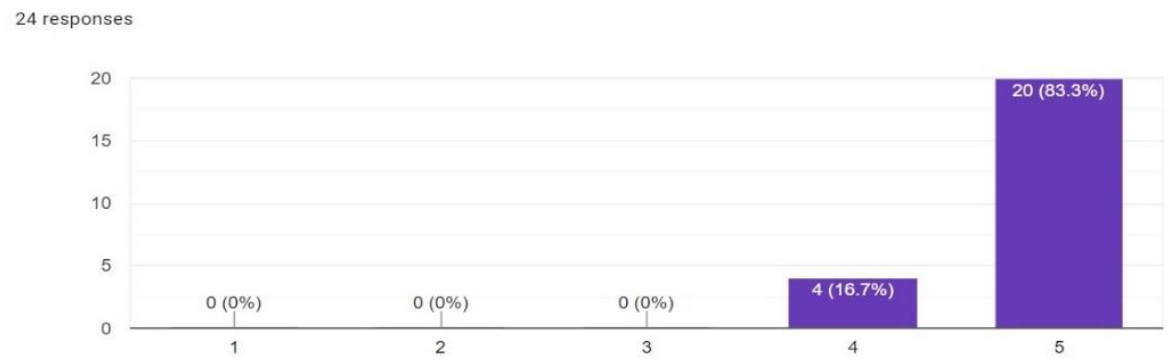

Grafik 4.1. Pengaruh Entitas Wisatawan Asing sebagai Indikator Pembelajaran Bahasa Inggris

Antusias masyarakat lokal untuk mempelajari Bahasa Inggris juga dapat di lihat dari respon masyarakat terhadap kegiatan belajar Bahasa Inggris yang diadakan oleh Banjar Tegal Gundul untuk masyarakat sekitar. Presepsi masyarakat menyatakan bahwa Bahasa Inggris mempermudah pelayanan kepada wisatawan asing, ditunjukan dari pernyataan responden Sangat Setuju 83.3\% dan Setuju 16.7\% dengan hal tersebut. 


\section{Oeumanitatis}

Journal on Language and Literature Vol. 6 No. 2 June 2020

24 responses

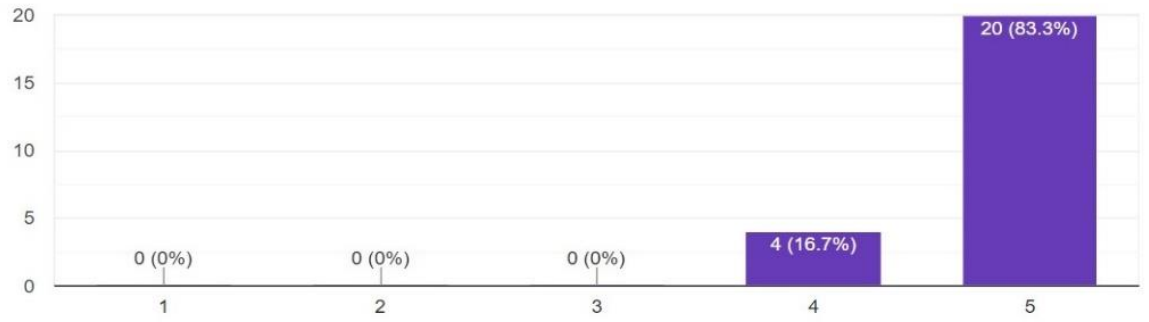

Grafik 4.2 Presepsi masyarakat terhadap pelayanan kepada Wisatawan Asing

Selain itu untuk orientasi masyarakat yang bahwa Belajar bahasa Inggris penting bagi saya karena orang akan lebih menghargai saya bila saya mempunyai kemampuan berbahasa Inggris yang baik, mendapatkan respon Sangat Setuju $58,3 \%$, Setuju 12.5\%, Netral 25\% dan Sangat Tidak Setuju 4,2\%

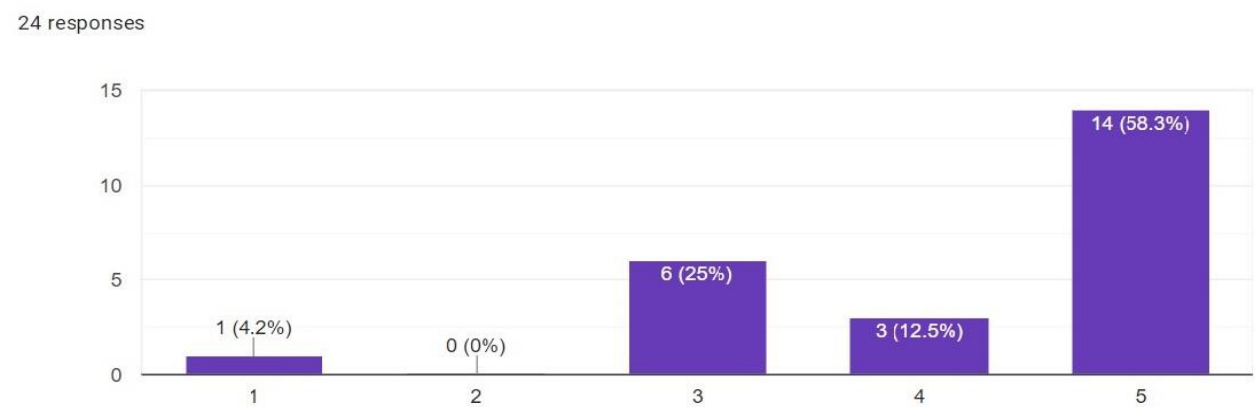

Grafik 4.3. Kemampuan Bahasa Inggris sebagai bentuk penghargaan

Minat belajar Bahasa Inggris yang tinggi ditunjukan masyarakat lokal Banjar Tegal Gundul, adanya pernyataan diperoleh dalam penelitian ini. 1) Belajar bahasa Inggris adalah pengalaman yang menyenangkan dan 2) Belajar bahasa Inggris hanya menghabiskan waktu saja. Pada pernyataan (1) mendapatkan respon 70,8\% menyatakan Sangat Setuju, 16,7\% menyatakan Setuju dan 12,5\% menyatakan Netral. 


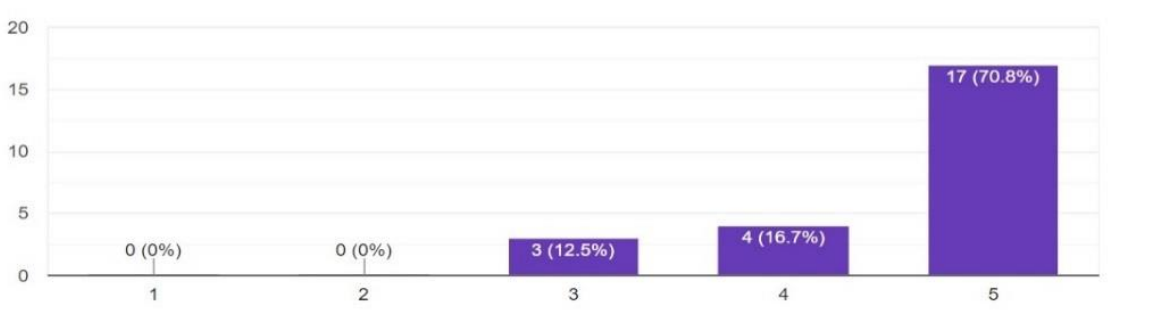

Grafik 4.4 Belajar bahasa Inggris adalah pengalaman yang menyenangkan

Sedangkan untuk pernyataan (2) responden menyatakan Sangat Tidak setuju $\mathbf{7 5 \%}$ atau 18 orang responden, Tidak setuju 17,7\% atau 4 orang dan Sangat setuju 8,3\% atau 2 orang responden (lihat grafik 5).

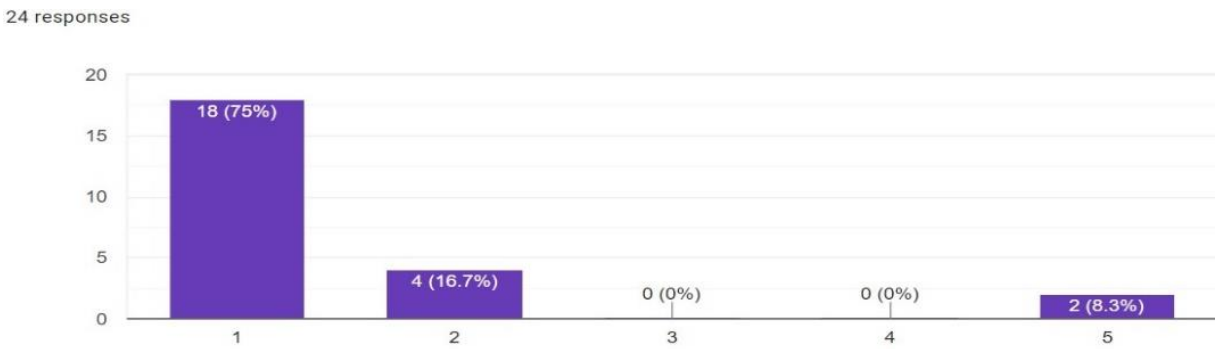

Grafik 4.5. Belajar bahasa Inggris hanya menghabiskan waktu saja

Dari pernyataan tersebut dapat disimpulkan bahwa minat belajar Bahasa Inggris untuk meningkatkan kemampuan masyarakat lokal masih memiliki nilai positif bagi 22 orang dari pada respon negative yang hanya dinyatakan oleh 2 orang responden. Kedua pernyataan di atas menunjukkan respons positif terhadap pembelajaran bahasa Inggris yang bertujuan untuk meningkatkan kemampuan bahasa Inggris bagi masyarakat, sehingga mereka dapat berkomunikasi dengan wisatawan dengan baik. Fenomena tersebut dibuktikan dengan temuan penelitian pada saat pengamatan di Penyewaan Motor yang dikelola oleh masyarakat lokal Banjar Tegal Gundul, berikut bentuk percakapan:

Lokasi : Rent Motor

Partisipan : 1. Kadek Suryanadi (Pemilik Usaha)

2. Guest 
Percakapan 1

Kadek : Halo. May I help you?

Guest : Yes, I need a bike to rent. Can I rent it here?

Kadek : Sure. For how long do you need?

Guest : I need a month, maybe more.

Kadek : Sorry. What is your name?

Guest : I am Mamik. And what is your name?

Kadek : I am Kadek. Nice to meet you.

Guest : Nice to meet you too. And Can I see your bikes?

Kadek : Yes, please. Here I do have different type of bikes and with different price. The ptice is Rp. 500.000 per month for the old bike and Rp. 1.000 .000 per month for the one is almost new.

Guest : What makes it different?

Kadek : Like you see here, this bike old and the CC is $108 \mathrm{CC}$ and this ine is almost new and the $\mathrm{CC}$ is $125 \mathrm{CC}$.

Guest : Ok. I take the cheaper one Rp. 500.000 per month.

Kadek : Are you sure? One thing you must to know, if you like doing travelling, you need a good bike and the $\mathrm{CC}$ of the bike will effect for the speed.

Guest : Eemm, but my budget is not enough if it is Rp. 1.000 .000 per month.

Kadek : How about if I give you Rp. 800.000 per month? But you rent for 3 months.

Guest : Ok. Sounds good. I rent 3 months.

Kadek : note. Before you sign it, please read the rules so you know all about the bike rent here.

Guest : Ok. I agree.

Kadek : Thank you and enjoy your travelling in Bali.

Berdasarkan percakapan diatas, ditemukan fungsi-fungsi Bahasa yang dirumuskan oleh Blundell. Untuk lebih jelasnya perhatikan table 4.6 


\section{OUmanitatis}

Journal on Language and Literature Vol. 6 No. 2 June 2020

\section{Table 4.6. Fungsi bahasa berdasarkan percakapan 1}

\begin{tabular}{|c|c|c|c|c|}
\hline No & Kalimat & $\begin{array}{l}\text { Fungsi } \\
\text { Bahasa }\end{array}$ & Gramatikal & $\begin{array}{c}\text { Tidak } \\
\text { Gramatikal }\end{array}$ \\
\hline 1 & Halo & Gretting & v & \\
\hline 2 & May I help you? & Offering & v & \\
\hline 3 & $\begin{array}{l}\text { - For how long do you need? } \\
\text { - What is your name? }\end{array}$ & $\begin{array}{l}\text { Asking for } \\
\text { information }\end{array}$ & $\mathrm{v}$ & \\
\hline 4 & $\begin{array}{l}\text { - I am Kadek } \\
\text { - Here I do have different type of bikes and with } \\
\text { different price. The ptice is Rp. } 500.000 \text { per month } \\
\text { for the old bike and Rp. } 1.000 .000 \text { per month for } \\
\text { the one is almost new. } \\
\text { - Like you see here, this bike old and the CC is } \\
108 C C \text { and this ine is almost new and the CC is } \\
125 \text { CC. }\end{array}$ & $\begin{array}{l}\text { Giving } \\
\text { Information }\end{array}$ & $\mathrm{v}$ & \\
\hline 5 & Nice to meet you & Saying Like & $\mathrm{v}$ & \\
\hline 6 & Are you sure? & Reminding & $\mathrm{v}$ & \\
\hline 7 & $\begin{array}{l}\text { One thing you must to know, if you like doing } \\
\text { travelling, you need a good bike and the CC of the } \\
\text { bike will effect for the speed. }\end{array}$ & $\begin{array}{l}\text { giving } \\
\text { opinion }\end{array}$ & $\mathrm{v}$ & \\
\hline 8 & $\begin{array}{l}\text { How about if I give you Rp. } 800.000 \text { per month? But } \\
\text { you rent for } 3 \text { months. }\end{array}$ & Persuading & $\mathrm{v}$ & \\
\hline 9 & $\begin{array}{l}\text { Can I make a copy of your passport please? And you } \\
\text { need to complete this note. Before you sign it, please } \\
\text { read the rules so you know all about the bike rent } \\
\text { here. }\end{array}$ & $\begin{array}{l}\text { Asking } \\
\text { someone to } \\
\text { do } \\
\text { something }\end{array}$ & $\mathrm{v}$ & \\
\hline 10 & Thank you and enjoy your travelling in Bali & $\begin{array}{l}\text { Say / Reply } \\
\text { to thank }\end{array}$ & v & \\
\hline
\end{tabular}

Berdasarkan penjelasan tabel diatas, peneliti menyimpulkan bahwa mereka sangat mampu berkomunikasi dalam bahasa Inggris. Adapun fungsi Bahasa yang digunakan meliputi ekspresi greeting, offering, asking and giving information, 


\section{Oeumanitatis}

Journal on Language and Literature Vol. 6 No. 2 June 2020

saying like, reminding, giving opinion, persuading, asking someone to do something dan say/rely to thank kepada pelanggan.

Pada lokasi pengamatan di Bali Made Guest House, ditemukan percakapan antara pegawai guest house dengan salah satu calon tamunya sebagai berikut:

Lokasi : Bali Made Guest House

Partisipan : 1. Ni Wayan Yuraeni (Pekerja)

\section{Levis (Guest)}

\section{Percakapan 2}

Wayan : Hi. Are you fried of Yati the one is text me Wayan on Saturday?

Guest : Yes, my name is Levis. Nice to meet you Wayan.

Wayan : Nice to meet you too. So now you here. Like I say here at Bali Made Guest House. We have rooms in Rp. 1.7 million per month, Rp. 5 million per month. What is your budget?

Guest : Can I see the room in Rp. 1.7 million per month?

Wayan : Sure. This is room in Rp. 1.7 million, Have around in the room, bathroom is outside behind the room below and have hot and cold shower, shared kitchen, Wi-Fi too.

Guest : This room is good but I have lots of stuff, maybe can I see the other room?

Wayan : Yes, please. I'll show you room in 5 Million per month.

This the room. Have air Cond in the room, bathroom is outside behind the room below and have hot and cold water, shared kitchen, Wi-Fi too.

Guest : This room is good but I have a lot of stuff. Maybe can I see the other room?

Wayan : Yes, please. I'll show you room in 3 Million per month.

This is the room, have private bath-tub, hot and coil shower, table, air Cond, shared kitchen and Wi-Fi too. The room more bigger too. Like you see here more fresh air, you come into the room coz this room is special with window. This room bright too. 
Guest : Yes I like this room and if I stay more than a month. Do you give me special price?

Wayan : I am so sorry, for the price. I can't make more cheaper than 3 Million coz this is price already low in this situation, Covid 19 make all low, no income, like you see I have more room is empty.

Guest : Ok. I take the room in 3 Million per month.

Wayan : Thanks and you can save my phone number, if you need something just text come or come to the front, there is my house.

Guest : Ok. Good. For the payment, can I do it now?

Wayan : Yes please. And I'll give you the bill. Thank you.

Dalam percakapan diatas ditemukan fungsi-fungsi bahasa, sebagai berikut pada table 2 :

Tabel 4.7. Fungsi bahasa berdasarkan percakapan 2

\begin{tabular}{|c|c|c|c|c|}
\hline No & Kalimat & Fungsi Bahasa & Gramatikal & $\begin{array}{c}\text { Tidak } \\
\text { Gramatikal }\end{array}$ \\
\hline 1 & $\begin{array}{l}\text { Hi. } \\
\text { Are you friend of Yati the one is text me on } \\
\text { Saturday? }\end{array}$ & $\begin{array}{l}\text { Gretting } \\
\text { Asking for } \\
\text { information }\end{array}$ & V & \\
\hline 2 & $\begin{array}{l}\text { Nice to meet you too. So now you here. } \\
\text { Like I say here at Bali Made Guest House. We } \\
\text { have rooms in } 1.7 \text { million rupiah per month, } 3 \\
\text { million rupiah per month and } 5 \text { million rupiah } \\
\text { per month. } \\
\text { What is your budget? }\end{array}$ & $\begin{array}{l}\text { Saying Like } \\
\text { Giving } \\
\text { Information } \\
\text { Asking for } \\
\text { information }\end{array}$ & $\mathrm{v}$ & \\
\hline 3 & $\begin{array}{l}\text { Sure } \\
\text { This is room in Rp. } 1.7 \text { million, have around in } \\
\text { the room, bath-room is outside behind the room }\end{array}$ & $\begin{array}{l}\text { Accepting } \\
\text { invitation } \\
\text { Giving } \\
\text { information }\end{array}$ & V & \\
\hline
\end{tabular}




\section{OUmanitatis}

Journal on Language and Literature Vol. 6 No. 2 June 2020

\begin{tabular}{|c|c|c|c|c|}
\hline No & Kalimat & Fungsi Bahasa & Gramatikal & $\begin{array}{c}\text { Tidak } \\
\text { Gramatikal }\end{array}$ \\
\hline & $\begin{array}{l}\text { below and have hot and cold shower, shared } \\
\text { kitchen, Wi-Fi too }\end{array}$ & & & \\
\hline 4 & $\begin{array}{l}\text { This the room. Have air Conditioner in the } \\
\text { room, bathroom is outside behind the room } \\
\text { below and have hot and cold water, shared } \\
\text { kitchen, Wi-Fi too. }\end{array}$ & $\begin{array}{l}\text { Giving } \\
\text { information }\end{array}$ & & \\
\hline 5 & $\begin{array}{l}\text { Yes, please. I'll show you room in } 5 \text { Million per } \\
\text { month. } \\
\text { This is the room, have private bath-tub, hot and } \\
\text { coil shower, table, air Cond, shared kitchen } \\
\text { and Wi-Fi too. The room more biger too. Like } \\
\text { you see here more fresh air, you come into the } \\
\text { room coz this room is special with window. } \\
\text { This room bright too. }\end{array}$ & $\begin{array}{l}\text { Accepting } \\
\text { invitation } \\
\text { Giving } \\
\text { Information }\end{array}$ & 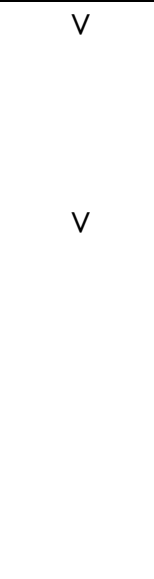 & \\
\hline 6 & $\begin{array}{l}\text { I am so sorry, for the price. } \\
\text { I can't make more cheap than } 5 \text { Million coz } \\
\text { this is price already low in this situation, } \\
\text { Covid } 19 \text { make all low, no income, like you see } \\
\text { I have more room is empty. }\end{array}$ & $\begin{array}{l}\text { Apologizing } \\
\text { Giving } \\
\text { Information } \\
\text { Persuading }\end{array}$ & V & \\
\hline 7 & $\begin{array}{l}\text { Thanks and you can save my phone number, if } \\
\text { you need something just text come or come to } \\
\text { the front, there is my house. }\end{array}$ & $\begin{array}{l}\text { Say / Reply } \\
\text { to thank } \\
\text { Offering } \\
\text { thing }\end{array}$ & V & \\
\hline
\end{tabular}

Dari kedua percakapan yang ditemukan, dapat disimpulkan bahwa kemampuan berbahasa Inggris dari masyarakat lokal Banjar Tegal Gundul Desa Tibubeneng, Kuta Utara, Badung, Bali, dipengaruhi oleh Faktor ekternal yaitu pengaruh dari intensitas komunikasi berbahasa Inggris dengan 
wisatawan asing dan factor internal yaitu dipengaruhi oleh latar belakang pendidikan masyarakat lokal(lihat grafik 6). Diketahui melalui kuesioner bahwa responden dalam penelitian ini menempuh pendidikan SMA hingga universitas/sederajat, sehingga minat belajar bahasa Inggris cukup tinggi karena mereka memiliki persamaan presepsi bahwa mereka akan mendapatkan banyak manfaat dengan memiliki keahlian berbahasa Inggris.

Pendidikan

24 responses

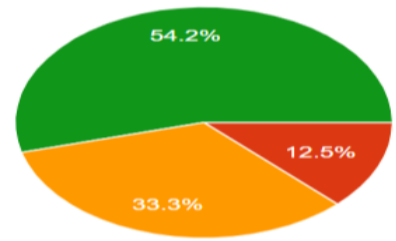

Grafik 4.8. Latar belakang pendidikan responden

\subsection{Sikap Bahasa Masyarakat Lokal Banjar Tegal Gundul, Badung - Bali terhadap Bahasa Inggris}

Sikap bahasa adalah posisi mental atau perasaan terhadap bahasa sendiri atau bahasa orang lain. Keadaan dan proses terbentuknya sikap bahasa tidak jauh dari keadaan dan proses terbentuknya sikap pada umumnya. Menurut Chaer dan Agustina (2010:149) Sikap bahasa dapat diamati melalui perilaku berbahasa atau perilaku tutur. Sikap bahasa juga merupakan peristiwa kejiwaan sehingga tidak dapat diamati secara langsung. Sikap bahasa tersebut meliputi tiga bagian atau komponen, yakni komponen kognitif, komponen afektif, dan komponen konatif. Peneliti dalam hal ini menggunakan ketiga komponen tersebut untuk mengetahui bagaimana sikap Bahasa masyarakat lokal Banjar Tegal Gundul Desa tibubeneng, Kuta Utara, Badung, Bali terhadap Bahasa Inggris. 


\section{Oeumanitatis}

\section{Journal on Language and Literature Vol. 6 No. 2 June 2020}

a) Komponen kognitif berhubungan dengan pengetahuan mengenai alam sekitar dan gagasan yang biasanya merupakan kategori yang dipergunakan dalam proses berpikir. Pada komponen ini sikap bahasa dilihat dari sudut pandang atau pendapat masyarakat lokal terhadap penutur bahasa dan bentuk bahasa Inggris. Melalui hasil kusioner di peroleh data bahwa masyarakat lokal memiliki sikap positif terhadap penutur Bahasa Inggris, kondisi tersebut dapat dilihat dari pernyataan responden. Hanya 15 responden atau 62.5\% menyatakan Sangat Setuju, 8 responden atau 33.3\% menyatakan Setuju dan 1 responden atau 4,2\% menyatakan Netral.

24 responses

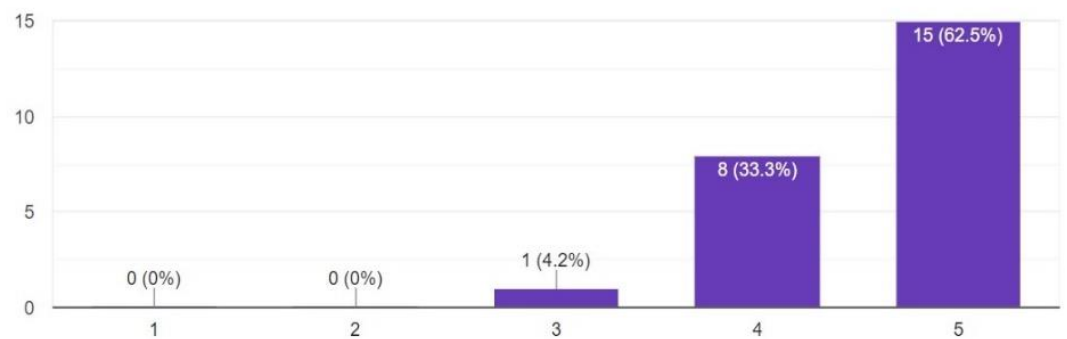

Grafik 7. Pandangan masyarakat lokal terhadap penutur Bahasa asing

b) Komponen afektif menyangkut masalah penilaian baik dan buruk, suka atau tidak suka terhadap sesuatu. Jika seseorang memiliki nilai rasa baik atau suka terhadap suatu keadaan, maka orang itu dikatakan memiliki sikap positif. Jika sebaliknya, disebut memiliki sikap negatif. Dalam penelitian ini untuk memilhat bagaimana perasaan terhadap bahasa atau penutur Bahasa Inggris tersebut juga dapat terwujud dalam bentuk perasaan senang ataupun tidak senang, dilihat dari beberapa pernyataan sebagai berikut :

1. Pernyataan bahwa saya sangat senang ketika berada dalam kelas pelatihan bahasa Inggris 


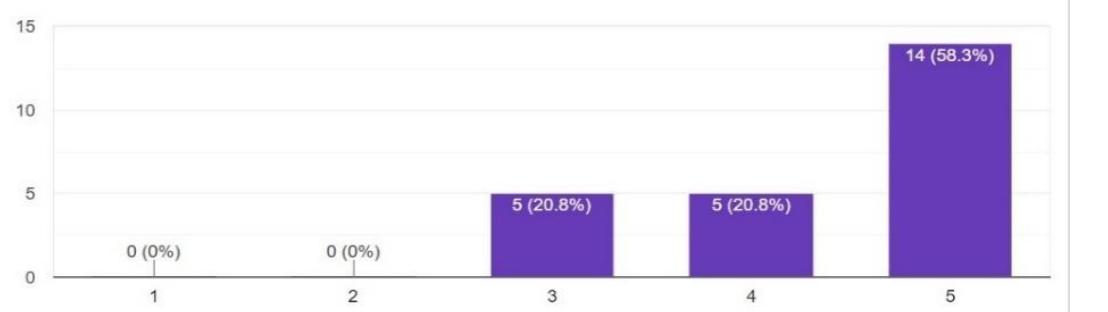

Grafik 8. Senang mengikuti pelatihan Bahasa Inggris

Dari pernyataan responden diperoleh 58.3\% menyatakan Sangat Setuju, $\mathbf{2 0 . 8 \%}$ menyatakan Setuju dan $\mathbf{2 0 , 8 \%}$ menyatakan Netral. Pernyataan positif dari masyarakat lokal, dikarenakan manfaat dari pembelajaran bahasa Inggris sangat dirasakan oleh masyarakat lokal Banjar Tegal Gundul-Badung Bali, berikut respon masyarakat untuk beberapa pernyataan pada kusioner:

2. Belajar bahasa Inggris penting bagi saya agar saya bisa mendapatkan konsumen wisatawan asing yang lebih banyak

24 responses

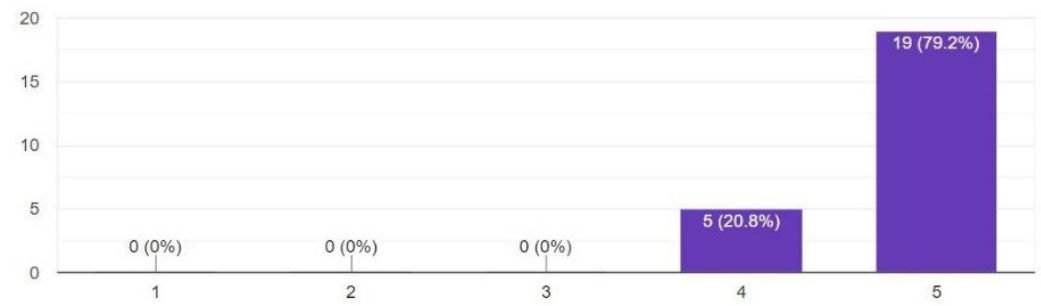

Grafik 4.10. Belajar Bahasa Inggris bias mendapatkan konsumen wisatawan asing lebih banyak

Dari pernyataan diatas menyatakan $\mathbf{7 9 . 2 \%}$ menyatakan Sangat Setuju dan 20.8\% menyatakan Setuju.

3. Belajar bahasa Inggris penting bagi saya agar saya bisa mendapatkan peluang pekerjaan yang lebih baik 


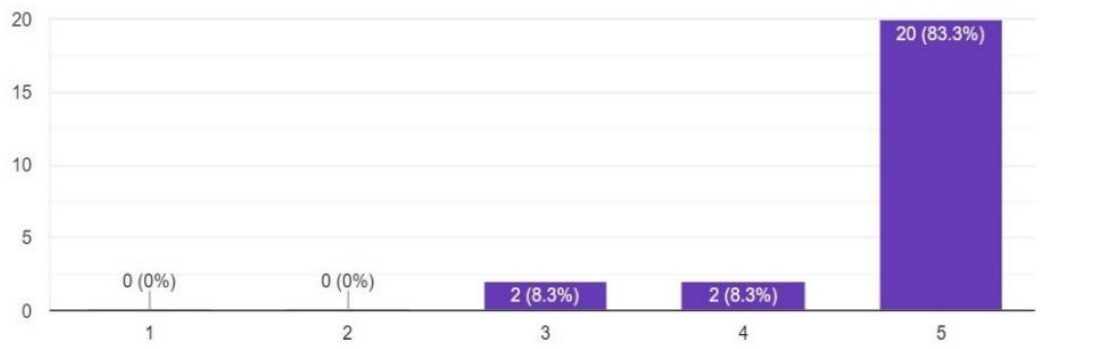

Grafik 4.11. Bahasa Inggris penting untuk mendapatkan peluang pekerjaan yang lebih baik

Dari pernyataan diatas menyatakan 83.3\% menyatakan Sangat Setuju,

8.3\% menyatakan Setuju dan 8.3\% menyatakan Netral.

4. Belajar bahasa Inggris penting bagi saya karena hal ini dapat memudahkan saya untuk bicara bahasa Inggris dengan wisatawan asing

24 responses

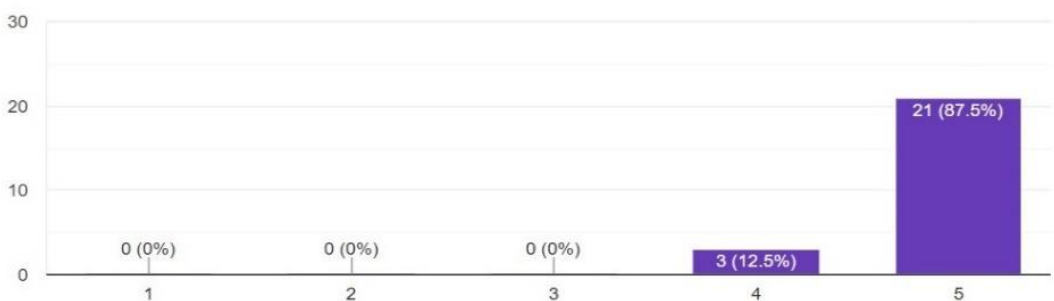

Grafik 4.12. Bahasa Inggris memudahkan untuk berkomunikasi dengan wisatawan asing

Dari pernyataan diatas menyatakan $\mathbf{8 7 . 5 \%}$ menyatakan Sangat Setuju dan $\mathbf{1 2 . 5 \%}$ menyatakan Setuju.

c) Komponen konatif dalam sikap bahasa berkenaaan dengan perilaku seseorang dalam menggunakan suatu bahasa. Perilaku seseorang dalam menggunakan suatu bahasa dengan baik atau benar. Yang dimaksud dengan menggunakan suatu bahasa dengan baik adalah digunakannya bahasa tersebut dengan baik sesuai dengan fungsi bahasa tersebut. Sedangkan, yang dimaksud dengan menggunakan bahasa dengan benar adalah digunakannya suatu bahasa sesuai dengan kaidah bahasa tersebut. Berdasarkan hasil pengamatan diperoleh 
bahwa kemampuan berbahasa Inggris masyarakat lokal Banjar Tegal Gundul, Desa Tibubeneng, Kuta Utara, Kabupaten Badung, Bali sangat baik karena penggunaan bahasa Inggris secara verbal sesuai dengan kaidah aturan gramatikal dalam bahasa Inggris. Selain itu juga hasil pengamatan diperoleh data non-verbal bahwa kemampuan menulis bahasa Inggris yang baik, berikut data yang diperoleh dari hasil pengamatan di lapangan:

Percakapan 3 : Melalui Whatsapp

Guest : Hi Kadek. My friend Yati Taringa gave me your number. I'm interested in the room in Berawa. In Bali Made Guest House.

Kadek : Yes, Bali Made Guest House, We have rooms available, price start from Rp. 1.7000 .000 per month til Rp. 5.000 .000 per month depended of your budget. Including electricity too.

Guest : Could I check the rooms on Monday?

Kadek : Sure

Guest : What time? I could come on early afternoon.

Kadek : At 1 or 2 is ok.

Guest : Ok. Sounds good

Kadek : See you tomorrow.

Dari percakapan tersebut dapat dilihat penggunaan Bahasa Inggris dalam bentuk tulisan sesuai dengan aturan gramatikal Bahasa Inggris. Sesuai hasil analisis data kuesioner dan hasil pengamatan tentang ketiga komponen sikap bahasa masyarakat lokal Banjar Tegal Gundul, Desa Tibubeneng, Kecamatan Kuta Utara, Badung, Bali dapat disimpulkan bahwa masyarakat lokal Banjar Tegal Gundul memiliki sikap bahasa yang sangat positif terhadap Bahasa Inggris.

\section{E. KESIMPULAN}

Dari hasil pengamatan diperoleh hasil bahwa Entitas wisatawan sangat mempengaruhi kemampuan berbahasa Inggris Masyarakat Lokal Banjar Tegal Gundul, desa Tibubeneng, Kuta Utara, Badung, Bali, hal tersebut dapat dilihat dari fungsi-fungsi Bahasa yang digunakan oleh masyarakat lokal sudah sesuai 
Journal on Language and Literature Vol. 6 No. 2 June 2020

dengan kaidah dalam penggunaan Bahasa Inggris yang baik dan benar. Adapun fungsi Bahasa yang digunakan oleh masyarakat lokal adalah menyatakan Greeting, Offering, asking for information, giving information, Saying Like, Giving opinion, persuading, asking someone to do something, Accepting invitation, apologizing, persuading, dan say/reply to thank. Penggunaan fungsi bahasa oleh masyarakat lokal, mampu menciptakan situasi peristiwa tutur berjalan dengan harmonis, komunikasi antara masyarakat lokal dan wisatawan asing khususnya dari Australia berjalandengan baik tanpa adanya kesalahanpahaman antaran kedua partisipan. Eksepresi yang dihasilkan dari penggunaan fungsi bahasa oleh masyarakat lokal mampu dipahami oleh wisatawan asing. Selain itu juga dapat disimpulkan bahwa kemampuan berbahasa Inggris dari masyarakat lokal Banjar Tegal Gundul, Desa Tibubeneng, Kuta Utara, Badung, Bali, dipengaruhi oleh faktor ekternal yaitu pengaruh dari intensitas komunikasi berbahasa Inggris dengan wisatawan asing dan factor internal yaitu dipengaruhi oleh latar belakang pendidikan masyarakat lokal itu sendiri. Diketahui bahwa responden dalam penelitian ini menempuh pendidikan SMA hingga universitas/sederajat, sehingga minat belajar bahasa Inggris cukup tinggi karena mereka memiliki persamaan presepsi bahwa mereka akan mendapatkan banyak manfaat dengan memiliki keahlian berbahasa Inggris. Dari hasil kusioner dan hasil pengamatan mengenai sikap bahasa Masyarakat Lokal Banjar Tegal Gundul, Desa Tibubeneng, Kuta Utara, Badung, Bali, diperoleh data bahwa Sikap positif terhadap bahasa Inggris ditunjukan oleh masyarakat lokal melalui tiga komponen yaitu Kognitif, Afektif dan Konatif. Hal ini juga menjadi indikator penguasaan bahasa Inggris oleh masyarakat lokal baik secara verbal ataupun non-verbal yang sangat baik.

\section{DAFTAR PUSTAKA}

Arikunto, Suharsimi. 1989. ProsedurPenelitian. Jakarta: Bina Angkasa.

Blundell, John, Jonathan Higgins, and Niggel Niddlemiss. 1982. Function in English. Oxford: Oxford University Press 


\section{Peumanitatis}

Journal on Language and Literature Vol. 6 No. 2 June 2020

BPS. 2018. Pendapatan Asli Daerah Kabupaten/Kota se-Bali, 2000-2017. https://bali.bps.go.id/dynamictable/2018/02/02/213/pendapatan-asli-daerah Kabupaten-kota-se-bali-2000-2016.html. Diakses 4 Januari 2019

Chaer, Abdul dan Leonie Agustina. 2004. Sosiolinguistik Perkenalan Awal.Jakarta: Rineka Cipta.

Fasold, Ralp. 2001. The Sociolinguistics of Society. Oxford: Basil Blackwell.

Harimurti Kridalaksana. 2001. Kamus Linguistik. Jakarta: PT. Gramedia Pustaka Utama.

https://badungkab.go.id/instansi/kutautara/baca-artikel/69/Kuta-Utara-Badung.html

https://www.cntraveler.com/galleries/2014-10-20/top-30-islands-in-the-worldreaders-choice-awards-2014

Kridalaksana, Harimurti. 2011. Fungsi Bahasa dan Sikap Bahasa. Flores: Nusa Indah.

Lambert. 1967. A Social Psyhology of Bilingualism. Journal of Social Issue, 91-109. in Pride and Holmes (1972).

Mahsun, Prof. 2007. Metode Penelitian Bahasa. Jakarta: PT RajaGrafindo Persada.

Partana, Paina dan Sumarsono. 2004. Sosiolinguistik. Yogyakarta: Sabda.

Pusat Bahasa Depdiknas. 2008. Kamus Besar Bahasa Indonesia (Edisi Ketiga). Jakarta: Balai Pustaka.

Pateda, Mansuer. 1994. Linguistik Sebagai Pengantar. Bandung: Angkasa.

https://badungkab.go.id/instansi/kutautara/baca-artikel/69/Kuta-Utara-Badung.html http://kampungkb.bkkbn.go.id/profile/1758

http://desacanggu.badungkab.go.id/page/1171/Sejarah-Desa-Canggu.html 


\section{Oeumanitatis}

Journal on Language and Literature

Vol. 6 No. 2 June 2020

- 